\title{
Identifying critical areas to reduce bycatch of coastal common bottlenose dolphins Tursiops truncatus in artisanal fisheries of the subtropical western South Atlantic
}

\author{
J. C. Di Tullio ${ }^{1,2, *}$, P. F. Fruet ${ }^{1,2}$, E. R. Secchi ${ }^{1,2}$ \\ ${ }^{1}$ Laboratório de Ecologia e Conservação da Megafauna Marinha (ECOMEGA), Instituto de Oceanografia, \\ Universidade Federal do Rio Grande, Caixa Postal 474, 96201-900 Rio Grande, RS, Brazil \\ ${ }^{2}$ Museu Oceanográfico ‘Prof. Eliézer de C. Rios', Universidade Federal do Rio Grande, Caixa Postal 379, \\ 96200-970 Rio Grande, RS, Brazil
}

\begin{abstract}
Many anthropogenic actions have an impact on coastal dolphins, with bycatch being one of the main threats. We describe the distribution patterns of common bottlenose dolphins Tursiops truncatus and periods of higher entanglement risk by the artisanal gillnet fishery in the Patos Lagoon estuary and along the adjacent coast of southern Brazil. A total of 136 dolphin groups and 187 gillnets were encountered in 69 surveys conducted between September 2006 and July 2009. Data were analyzed in relation to environmental, spatial and temporal variables using generalized additive models and a spatially adaptive local smoothing algorithm for model selection. In both areas, dolphin densities increased as distance to the estuary mouth decreased. For the estuary area, water salinity and temperature influenced dolphin distribution. Along the adjacent coast, dolphin densities were higher with distance to shore as well as in the north area during the warm period. Patterns of dolphin distribution were probably a response to the presence of preferred prey or avoidance of human-related disturbance. Kernel density showed that fishing effort was distributed along the entire surveyed area inside the estuary, while along the adjacent coast it was higher in the south compared to the north area in the warm period. The overlap between gillnets and dolphins increased considerably from the cold $(33.8 \%)$ to the warm $(48.6 \%)$ period. Seasonal variation in fishing effort and distribution affect the overlap and the risk of dolphin entanglement. Based on the findings of this study, a fishing exclusion area aimed at reducing bycatch was established by the Brazilian Environmental Agency.
\end{abstract}

KEY WORDS: Conservation strategies - Artisanal gillnet fisheries - Patos Lagoon estuary · Generalized additive models $\cdot$ Fisheries-dolphin overlap

\section{INTRODUCTION}

The coastal habitat of many dolphin populations overlaps with human activities, and these populations face the impacts, for example, of competition with fisheries, pollution, habitat degradation, coastal development and increasing underwater noise (Reeves et al. 2003, 2013). However, mortality due to entan-

*Corresponding author: ditullio.juliana@gmail.com glement in fishing gears such as gillnets, trawls and crab pots is the main threat to the survival of many of these populations (e.g. Noke \& Odell 2002, Díaz López 2006, Gonzalvo et al. 2008). In recent years there have been increased efforts to investigate the impact of fisheries on cetaceans and how to mitigate it (e.g. Brown et al. 2013, Stolen et al. 2013, Waples et al. 2013). Understanding distribution patterns of 
dolphins threatened by human activities can be of particular use in informing decision makers about appropriate actions for their protection.

Prey distribution and abundance are key factors in determining the spatial and temporal patterns of dolphins. In fine-scale studies, however, it is often challenging to collect and analyze the prey availability data required to understand this relationship (Acevedo-Gutierrez \& Parker 2000, Heithaus \& Dill 2002, 2006). Habitat features such as depth, slope and distances from rivers, estuaries or coast might trigger oceanographic processes that enhance local productivity or favor prey capture (e.g. Ballance 1992, Parra 2006, Pirotta et al. 2011). Therefore, these variables are often considered useful proxies for prey availability, and dolphins preferred habitats have been identified without direct prey distribution data (e.g. Torres et al. 2008, MacLeod et al. 2014).

The common bottlenose dolphin Tursiops truncatus has a wide range and is found in coastal and pelagic waters (Wells \& Scott 1999). Long-term studies of coastal bottlenose dolphins around the world have shown that local communities generally number few individuals, display small home ranges and form genetically distinct units even at small geographic scales (Parsons et al. 2002, Tezanos-Pinto et al. 2009, Fernández et al. 2011). In southern Brazil, coastal bottlenose dolphins are structured into several coastal communities (Genoves 2013), some with remarkably low genetic diversity (Fruet et al. 2014). The term 'community' refers to a group of individuals that share large portions of their ranges and interact with each other more than with other members in adjacent waters (sensu Wells et al. 1987). The largest known discrete community, recently estimated at 86 individuals (95\% CI: 78 to 95) (Fruet et al. 2011, 2015), inhabits the Patos Lagoon estuary (PLE) and surrounding coastal areas year round (Mattos et al. 2007). This community occasionally interacts with coastal communities to the north and south of the estuary (Genoves 2013, Fruet et al. 2014). An analysis based on more than $30 \mathrm{yr}$ of stranding data revealed a marked increase in mortality of bottlenose dolphins in the vicinities of the estuary after 2002 (Fruet et al. 2012). This mortality also exhibited a strong seasonal pattern, from mid austral spring to late summer (November to March), which coincides with an intensive artisanal gillnet fishery in coastal waters adjacent to the PLE (Klippel et al. 2005). Many of the dolphins found washed ashore during this season present net marks or body mutilations and bycatch is considered the major source of dolphin mortality (Fruet et al. 2012). Hence any conservation plan for this dolphin community should take into account information on the relevant habitat characteristics that determine dolphin and artisanal fishery distributions. In this study we aimed to investigate the distribution patterns of bottlenose dolphins in PLE and the adjacent marine coast, to determine the extent to which their distribution overlaps with artisanal gillnet fisheries, and to identify variables that might explain these patterns.

\section{MATERIALS AND METHODS}

\section{Study area}

The Patos Lagoon is located along Rio Grande do Sul state coast, southern Brazil (Fig. 1), and is connected to the Atlantic Ocean through a permanent narrow channel ( 0.5 to $3.0 \mathrm{~km}$ wide) fixed by 2 rocky jetties, approximately $4 \mathrm{~km}$ long (Kjervfe 1986). The estuarine area is in the southern portion of the lagoon and is characterized by shallow bays, $80 \%$ of which are $<2 \mathrm{~m}$ in depth. Deeper waters are restricted to the navigation channel and can reach up to $20 \mathrm{~m}$ at the entrance of the estuary where the Rio Grande Port, one of the major ports in Brazil, is located. The lower estuary is subject to intense cargo-ship and fishingboat traffic as well as to extensive artisanal fishing and industrial activities (Tagliani et al. 2003).

The discharge of nutrient-rich water from the lagoon into the oceanic coastal areas and the intrusion of seawater into the estuary play crucial roles in the maintenance of productivity of this coastal ecosystem (Abreu \& Castello 1998). The PLE and the adjacent marine system are biologically connected as the life cycles of many invertebrates and fish depend on both systems, making the estuary an important breeding and feeding area of many fish and crustacean species (Haimovici et al. 2006, Dumont \& D'Incao 2011, Garcia et al. 2012).

The artisanal fishing fleet operates year round and follows a seasonal pattern according to local changes in abundance of target species (Reis et al. 1994, Kalikoski \& Vasconcellos 2012). Until the early 1980s, artisanal fisheries were restricted to the estuary. The collapse of estuarine fish stocks, caused by increased fishing effort and power, resulted in an expansion of the fishing areas to the adjacent marine coast (Reis \& D'Incao 2000). Despite a generally decreasing trend in artisanal fishing effort in the PLE, the number of trammel, fixed and drift gillnets in the lower estuary and adjacent marine coast (i.e. the area preferred by bottlenose dolphins) is still high, especially during 
the whitemouth croaker (Micropogonias furnieri) season in summer (Reis \& D'Incao 2000, Kalikoski et al. 2002, Kalikoski \& Vasconcellos 2012).

\section{Survey design}

Surveys were carried out from a $4.8 \mathrm{~m}$ aluminum boat with a 60 HP outboard engine at speeds around 18 to $22 \mathrm{~km} \mathrm{~h}^{-1}$. The speed was set based on a trade-

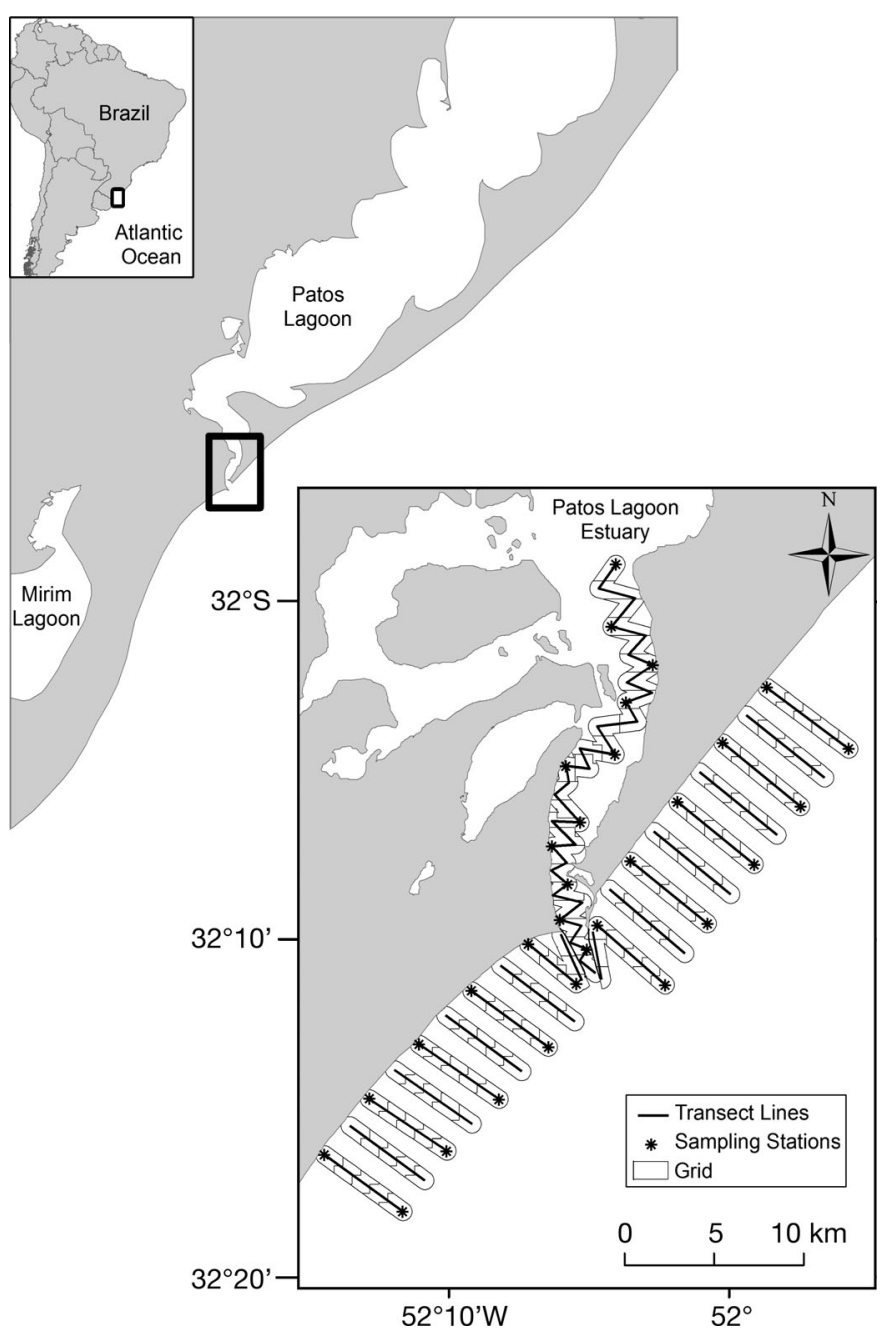

Fig. 1. Study area (black square) where surveys of bottlenose dolphins Tursiops truncatus and artisanal fisheries activity were conducted in the mouth of the Patos Lagoon estuary and along the adjacent coast of southern Brazil between 2006 and 2009. Inset: Transect lines (black lines) followed during boat surveys. Dolphin sightings within a strip $500 \mathrm{~m}$ wide along each side of the transect line (areas enclosed by thinner light grey lines) were recorded. Dolphins or nets sighted within a strip $500 \mathrm{~m}$ wide along each side of the transect line (areas enclosed by thinner light gray lines) were recorded. These areas are approximately $1 \mathrm{~km}^{2}$ (grid) and were used for modeling purposes. Asterisks show sampling stations where environment data were measured off between sampling area coverage and chances of detecting dolphins. For logistical reasons, the study area was divided into 3 sub-areas (estuary, north coastal and south coastal), such that each could be fully surveyed in $1 \mathrm{~d}$ (Fig. 1). Inside the estuary, 32 pre-defined zigzag transects (mean length $1.48 \mathrm{~km}$, SE $0.07 \mathrm{~km}$ ) were followed between the inner part of the lower estuary and the mouth, giving a total surveyed area of approximately $40 \mathrm{~km}^{2}$. The coastal area was split into areas south and north of the jetties, each being covered by 10 linear transects. The closest transects to the estuary followed the length of the jetties $(2.8 \mathrm{~km}$ in the south and $3.2 \mathrm{~km}$ in the north areas) and angle. The other 9 transects were each $5 \mathrm{~km}$ long and $2 \mathrm{~km}$ apart. Each transect line was placed roughly perpendicular to the coastline and isobaths, aiming at a homogenous effort with respect to depth, and distance from shore and from the entrance of the estuary (Buckland et al. 2001). The initial point of surveys was alternated within the areas.

\section{Data collection and analyses}

The survey team included 1 observer responsible for detecting and for counting the dolphins, i.e. the data recorder, who was in charge of both sighting dolphins and counting fishing nets, and the helmsman. Whenever dolphins were sighted, the transect line was abandoned and the boat was slowed to approach the animals for a better estimation of group size. The geographical position of the group was recorded using a hand held Global Positioning System (GPS). Time spent at each sighting was no longer than $30 \mathrm{~min}$, at which point the survey was resumed from the initial sighting location. The fishing buoys and sticks with flags used by the artisanal fishermen to fix their nets were counted along transects, and the geographic position was taken when nets were perpendicular to the observer. The number of buoys and/or flags was used as a relative index of fishing effort (nets km${ }^{-2}$ ).

The detectability of dolphins can vary depending on e.g. distance from transect line, observer and weather conditions. The latter 2 were minimized as the surveys were undertaken by the same observers and restricted to sea states $\leq 3$ on the Beaufort scale. To minimize dolphin and net counting errors or variation in detection probability, only sightings and nets detected within a strip $500 \mathrm{~m}$ wide along each side of the transect line were taken into account. Thus, the prior assumption that all dolphins (and 
nets) would be detected within the buffer area is probably met. This buffer area was split into grid cells of approximately $1 \mathrm{~km}^{2}$ (Fig. 1). Each grid was characterized by spatial (e.g. distance from coast and estuary mouth, depth, slope) and environmental covariates (e.g. temperature, salinity, transparency). The former were fixed covariates and their values were measured on the center of each grid. Environmental covariates, on the other hand, were collected in all surveys on predefined sampling stations. Since values of temperature and salinity did not vary between sampling stations within transect in the same survey, no interpolation was necessary. The values in each station were thus assigned to the nearest grids.

Data on water transparency (Secchi disk), surface and bottom temperature and salinity were taken in pre-established sampling stations along transects (Fig. 1), using a thermometer attached to a Nansen bottle and a salinometer, respectively. Three field trips using a jet ski equipped with a DGPS (Differential Global Positioning System) coupled to an echo sounder were conducted following the same survey design to obtain detailed bathymetric data with accurate positioning for the entire study area. These data were used to generate a bathymetric raster using a natural neighbor method interpolation, which does not generate values out of the range data (Watson 1992). The slope values were acquired using the slope tool from the Spatial Analyst extension in the ArcGIS program (ESRI version 9.2). The spatial covariates distance to shore and distance to the estuary mouth were determined using the Euclidean Distance tool of the ArcGIS program.

Table 1. Variables used in the exploratory analyses of bottlenose dolphin Tursiops truncatus distribution in the Patos Lagoon estuary and adjacent coast of southern Brazil. $\Delta$ : difference between surface and bottom values; CM: coastal areas; EM: estuary areas

\begin{tabular}{|lllc|}
\hline Variables & Models & Unit & $\begin{array}{c}\text { Abbreviations } \\
\text { of variables }\end{array}$ \\
\hline $\begin{array}{l}\text { Environmental } \\
\text { Temperature (surface; bottom; } \Delta \text { ) }\end{array}$ & EM, CM & Continuous ( $\left.{ }^{\circ} \mathrm{C}\right)$ & sst; sbt; dift \\
$\begin{array}{l}\text { Salinity (surface; bottom; } \Delta \text { ) } \\
\text { Transparency }\end{array}$ & EM, CM & Continuous (\%) & ssal; bsal; difsal \\
Spatial & EM, CM & Continuous (m) & tran \\
$\begin{array}{l}\text { Distance from the estuary mouth } \\
\text { Distance to coast }\end{array}$ & EM, CM & Continuous (m) & dem \\
Area & CM & Continuous (m) & dcoast \\
$\begin{array}{l}\text { Depth } \\
\text { Slope }\end{array}$ & CM & Factor (south, north) & ar \\
Temporal & EM, CM & Continuous (m) & dep \\
Period & EM, CM & Continuous ( $\left.{ }^{\circ}\right)$ & slp \\
& & & peri \\
\hline
\end{tabular}

\section{Effect of environmental, spatial and temporal variables on bottlenose dolphin distribution}

Exploratory data analyses were conducted following Zuur et al. $(2007,2009,2010)$ to check for outliers, collinearity, heterogeneity and other potential problems of the response and explanatory variables that could affect model fitting (Table 1). Temporal variations in dolphin and net densities were investigated considering cold (May to October) and warm (November to April) periods, which were defined according to mean sea surface temperature (sst) obtained during the surveys. Spearman correlation tests and variance inflation factors (VIF) were used to assess the collinearity of the explanatory variables considering a threshold of VIF $=3$ (Zuur et al. 2010). The explanatory variables which showed a significant correlation ( $\mathrm{r}>0.80$ ) and a high VIF value (VIF > 3) were not used together in the same model. Due to differences in spatial and environmental characteristics (e.g. depth, wave exposure, gradients in temperature and salinity) as well as sampling design between the estuary and the adjacent coast, models were fitted separately, considering the area (estuary and coast).

\section{Generalized additive models (GAMs)}

The environmental, temporal and spatial explanatory variables that described the distribution patterns of bottlenose dolphins (number of dolphins per $\mathrm{km}^{2}$ ) were investigated using GAMs. GAMs are extensions of generalized linear models which use a nonlinear link function to model the relationship between the response and explanatory variables without imposing parametric constraints (Hastie \& Tibshirani 1990, Venables \& Dichmont 2004). The models were built using the $m g c v$ package in $\mathrm{R}$ version 3.1.2 (R Development Core Team 2014). A quasiPoisson family, to account for overdispersion (McCullagh \& Nelder 1989, Venables \& Dichmont 2004), and a logarithmic link function were used in the models. The area of each grid was used as an offset of the number of dolphins because not all grids had the same area. 


\section{Model selection}

The spatially adaptive local smoothing algorithm (SALSA) was used for model selection through the MRSea package (Scott-Hayward et al. 2013). SALSA automatically chooses the location and number of knots in the spline regression model, based on the fit criteria and maximum Pearson residuals, respectively (Walker et al. 2011). Bayesian information criterion score for over-dispersed data (QBIC) was used for the model selection fit criteria, which is based on a likelihood function to compare nonnested models by penalizing for the number of parameters and sample size (Redfern et al. 2006). During the process using the 'runSALSA1D_with removal' function, $k$-fold cross-validation was also used to choose between models with covariates as a smoother-based term, linear term or omitting each term altogether. Once the model reached the best fit, some variables in the models were replaced, one at a time, by another variable that had been correlated in the data exploration and SALSA was run again. Factor and interaction between variables were tested manually by ANOVA function using F-test in car package (Fox \& Weisberg 2011). The procedure was repeated until the model with the lowest QBIC score was obtained after testing all the possibilities.

Model assessment was verified by creating 1000 over-dispersed Poisson data sets (simulated data) generated using this study data set. The models selected by SALSA were then fitted to these simulated data sets and plotted to graphs to compare the observed and simulated data mean variance relationship, residuals and pseudo- $\mathrm{R}^{2}$ (squared correlation between observed and fitted values under the selected model). The mean-variance relationship was assessed using the ggplot2 package (Wickham 2009) and the residual independence using the 'acf' function (stats package in R). A histogram using the function 'hist' (graphics package in R) was generated to verify pseudo- $\mathrm{R}^{2}$ for all simulated models and those obtained by the real data set.

\section{Overlap between dolphins and artisanal gillnet fishery}

The relative density of dolphins and buoys and/or flags was estimated considering the number of individuals per area covered, which was calculated according to the effort of each survey. Non-parametric Mann-Whitney $U$-tests and Kruskal-Wallis $H$-tests were used to verify for differences in mean densities of dolphins and nets between sampling time periods and areas, respectively.

A fixed kernel density was estimated to compare dolphin and fishing net distribution areas in warm and cold periods. This density estimator takes the sighting position into account within a searching area and considers the number of individuals or nets in each position. The influence of sightings in nearby areas decreases as distance increases following a normal distribution. Through this method the area near the sightings with larger numbers of individuals or fishing nets had higher density values than distant areas (ESRI 2001).

Representative areas (RAs) used by dolphins and fisheries were delimited by contour lines representing the boundary of the area which contains a percentage of a probability density distribution. The area was considered representative if it contained on average $90 \%$ of the sighting positions which were used to generate the estimated kernel density. These areas were obtained through the Hawths tools extension for the ArcGIS (ESRI, version 9.2). RAs were determined for the warm and cold periods. Areas of overlap between dolphins and fishing nets were established according to the intersection of their representative areas for both warm and cold periods.

The percent area overlap (PAO) was determined following Atwood \& Weeks (2003):

$$
\mathrm{PAO}=\left(\frac{A d_{1} f}{A d} \times \frac{A d_{,} f}{A f}\right)^{0.5}
$$

where $A d, f$ is the overlap representative area between dolphins and fisheries, $A d$ is the representative area for dolphins and $A f$ is the representative areas for fisheries.

All statistical analyses were performed using $\mathrm{R}$ and BioStat (version 5.3, Ayres et al. 2007). A significance level of $5 \%$ was adopted for all tests.

\section{RESULTS}

Between September 2006 and July 2009, 134 groups of bottlenose dolphins and 187 gillnets were encountered in 69 surveys totaling $2980.9 \mathrm{~km}^{2}$ of observation effort. The number of surveys varied among areas (25 were carried out inside the estuary, and 18 and 26 in the north and south coastal areas, respectively), time periods (28 were conducted during cold and 41 in warm periods) and years (6 in 2006, 25 in 2007, 21 in 2008 and 17 in 2009) (Table 2). 
Table 2. Number of surveys carried out, and numbers of bottlenose dolphin groups and individuals sighted in cold (May to October) and warm (November to April) periods between September 2006 and July 2009 in Patos Lagoon estuary and adjacent coastal areas of southern Brazil

\begin{tabular}{|llrrrrr|}
\hline \multirow{2}{*}{ Area/Period } & 2006 & 2007 & 2008 & 2009 & Total \\
\hline Coastal & & & & & & \\
Warm & Surveys & 1 & 11 & 12 & 6 & 30 \\
& Groups & 0 & 18 & 19 & 14 & 51 \\
& Individuals & 0 & 142 & 126 & 100 & 368 \\
Cold & Surveys & 1 & 5 & 3 & 5 & 14 \\
& Groups & 3 & 15 & 12 & 13 & 43 \\
& Individuals & 16 & 95 & 55 & 113 & 279 \\
Estuary & & & & & & \\
Warm & Surveys & 2 & 3 & 3 & 3 & 11 \\
& Groups & 5 & 5 & 4 & 7 & 21 \\
Cold & Individuals & 45 & 23 & 19 & 48 & 135 \\
& Surveys & 2 & 6 & 3 & 3 & 14 \\
& Groups & 6 & 4 & 5 & 4 & 19 \\
& Individuals & 27 & 40 & 21 & 19 & 107 \\
\hline
\end{tabular}

\section{Effects of environmental, spatial and temporal variables on bottlenose dolphin distribution}

The explanatory variables considered in the estuary and coastal models are listed in Table 3. The best models selected for both areas did not show significant non-linear relationships of dolphin density with all the explanatory variables (Tables 4 \& 5). Model assessment for both areas showed mean-variance relationship and a reasonable pseudo- $\mathrm{R}^{2}$ value when compared to the simulations (Figs. $2 \& 3$ ) and there was no evidence of residual correlation of both models (Figs. 4 $\& 5)$. The variables retained in the estuary model were distance to the estuary mouth (dem), surface water salinity (ssal) and temperature (sst) (Fig. 4). The smooth curves showed that bottlenose dolphins were more likely to be found in areas closer to the estuary mouth and occurred at all ranges of surface salinity and temperature (Fig. 4A-C). For the coastal area, dolphin relative density increased as distance to shore and to the estuary mouth decreased (Fig. 5A,B). The interaction between area and period showed that there was a lower relative density of dolphins in the south area on the warm period compared to the intercept; however, this was not significant (Table 5). No environmental variables were retained in this coastal model.

\section{Overlap between dolphins and artisanal gillnet fishery}

In general, there were no significant differences between the number of nets found in the study area
Table 3. Environmental, temporal and spatial explanatory variables used in the Generalized Additive Models (GAMs) to describe the distribution patterns of bottlenose dolphins Tursiops truncatus in estuary and coastal areas. Variables separated by slashes (/) were tested in different models due to collinearity. $\Delta$ : difference between surface and bottom values

\begin{tabular}{|lc|}
\hline Variables & $\begin{array}{c}\text { Variance inflation } \\
\text { factor (VIF) }\end{array}$ \\
\hline Estuary area & \\
Surface temperature / & $1.40 / 1.24 / 1.73$ \\
bottom temperature / period & \\
$\Delta$ temperature & 1.72 \\
Surface salinity / bottom salinity & $1.61 / 1.95$ \\
$\Delta$ salinity & 1.61 \\
Transparency & 1.14 \\
Distance from estuary mouth & 1.57 \\
Depth & 2.16 \\
Slope & 1.76 \\
Coastal area & \\
Surface temperature / & 1.99 / $1.79 / 1.64$ \\
bottom temperature / period & 1.36 \\
$\Delta$ temperature & $1.65 / 1.50$ \\
Surface salinity / bottom salinity & 1.57 \\
$\Delta$ salinity & 1.21 \\
Transparency & 1.08 \\
Distance from estuary mouth & 1.02 \\
Distance to coast & 1.05 \\
Area &
\end{tabular}

Table 4. Results of the generalized additives models (GAMs) selected for bottlenose dolphin (Tursiops truncatus) density in the estuary area. F-values, $t$-values, p-values (Pr) and degrees of freedom (df) are given for the explanatory variables. The pseudo- $\mathrm{R}^{2}$ value (the square of the correlation between observed and fitted values) is also shown. sst: sea surface temperature; dem: distance from the estuary mouth; ssal: surface salinity

\begin{tabular}{|lcc|}
\hline Explanatory & \multicolumn{1}{c|}{ Model results (estuary area) } \\
variable & & \\
\hline Intercept & Estimate & 1.84 \\
& $t$ & 1.30 \\
sst & $\operatorname{Pr}(>|t|)$ & 0.19 \\
& Estimate & -2.06 \\
& $F$ & 1.66 \\
& $\operatorname{Pr}(>F)$ & 0.17 \\
dem & $\mathrm{df}$ & 3 \\
& Estimate & -5.11 \\
& $F$ & 36.18 \\
& $\operatorname{Pr}(>F)$ & $2 \times 10^{-16}$ \\
ssal & $\mathrm{df}$ & 3 \\
& Estimate & 1.62 \\
& $F$ & 2.89 \\
& $\operatorname{Pr}(>F)$ & 0.035 \\
Pseudo- $\mathrm{R}^{2}$ & $\mathrm{df}$ & 3 \\
& 0.47 & \\
\hline
\end{tabular}


Table 5. Results of GAMs selected for bottlenose dolphin (Tursiops truncatus) density in the coastal area. F-values, $t$ values, p-values (Pr) and degrees of freedom (df) are given for the explanatory variables. The pseudo- $\mathrm{R}^{2}$ value is also shown. peri (warm): warm period; ar (south): south coastal area; dem: distance from the estuary mouth; dcoast: distance from the coast; peri (warm) ${ }^{*}$ area (south): interaction term between warm period and south coastal area

\begin{tabular}{|c|c|c|}
\hline Explanatory & \multicolumn{2}{|c|}{ Model results (coastal area) } \\
\hline Intercept & $\begin{array}{c}\text { Estimate } \\
\quad t \\
\operatorname{Pr}(>|t|)\end{array}$ & $\begin{array}{c}5.79 \\
7.798 \\
1.07 \times 10^{-14}\end{array}$ \\
\hline peri (warm) & $\begin{array}{c}\text { Estimate } \\
F \\
\operatorname{Pr}(>F) \\
\text { df }\end{array}$ & $\begin{array}{c}0.13 \\
2.39 \\
0.12 \\
1\end{array}$ \\
\hline ar (south) & $\begin{array}{c}\text { Estimate } \\
\qquad F \\
\operatorname{Pr}(>F) \\
\text { df }\end{array}$ & $\begin{array}{c}0.37 \\
0.27 \\
0.6 \\
1\end{array}$ \\
\hline dem & $\begin{array}{c}\text { Estimate } \\
F \\
\operatorname{Pr}(>F) \\
\text { df }\end{array}$ & $\begin{array}{c}-6.07 \\
19.42 \\
1.19 \times 10^{-14} \\
4\end{array}$ \\
\hline dcoast & $\begin{array}{c}\text { Estimate } \\
F \\
\operatorname{Pr}(>F) \\
\text { df }\end{array}$ & $\begin{array}{c}-1.52 \\
129.20 \\
2.2 \times 10^{-16} \\
1\end{array}$ \\
\hline peri (warm)* area (south) & $\begin{array}{c}\text { Estimate } \\
F \\
\operatorname{Pr}(>F) \\
\text { df }\end{array}$ & $\begin{array}{c}-084 \\
3.35 \\
0.06 \\
1\end{array}$ \\
\hline Pseudo- $\mathrm{R}^{2}$ & 0.1 & \\
\hline
\end{tabular}

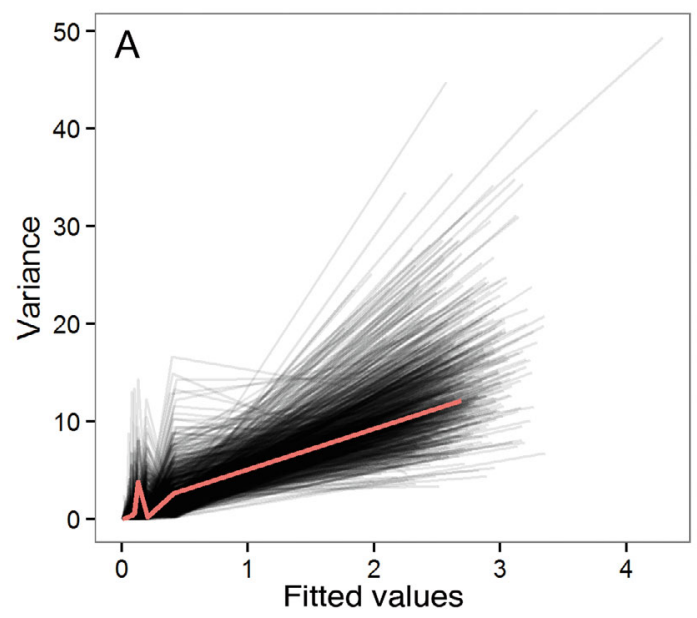

between time periods, when the adjacent coastal areas (north and south) and estuary were compared and between time periods inside the estuary (Fig. 6). In the warm period, relative net density to the south was higher than in the north area $(H=7.0912, \mathrm{p}=$ 0.03 ) and when compared to the same area (south) in the cold period ( $U=37.5, \mathrm{p}=0.03$ ) (Fig. 6)

The RAs used by dolphins and fisheries in warm months were approximately 74.5 and $117 \mathrm{~km}^{2}$, respectively (Fig. 7A,B). During the cold period, the RA used by dolphins was similar to warm months (66.2 $\mathrm{km}^{2}$ ) (Fig. 7B). On the other hand, the artisanal gillnet fishery used less than half the area in cold months $\left(59.6 \mathrm{~km}^{2}\right)$ compared to warm months (Fig. 7B). The overlap of RAs between dolphins and fisheries was twice as large $\left(45.4 \mathrm{~km}^{2}\right)$ in warm months as in cold months $\left(21.2 \mathrm{~km}^{2}\right)$, representing $48.6 \%$ and $33.8 \%$ of the dolphin usage areas, respectively (Fig. 8). Regardless of the time periods, there was an overlap between dolphins and fisheries in the area close to the estuary mouth inside the estuary and in the coastal area near the jetties.

\section{DISCUSSION}

\section{Effects of environmental, spatial and temporal variables on bottlenose dolphin distribution}

The aim of this study was to describe the distribution patterns of dolphins in the PLE and adjacent marine coast. Common biases in analyzing small-

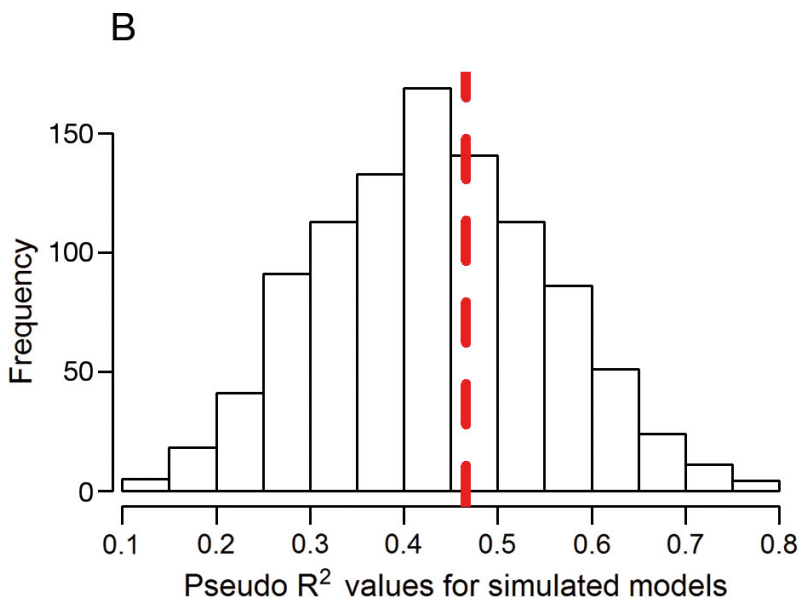

Fig. 2. Estuary area model assessment. (A) Mean variances of simulated models (black lines) generated using data set from this study assuming over-dispersed Poisson distribution. The red line shows the value obtained for the estuary model selected using the spatially adaptive local smoothing algorithm (SALSA). (B) Histogram of frequency of pseudo- $R^{2}$ values (the square of the correlation between observed and fitted values) for simulated models compared to the value obtained for the selected model (red dashed line) 

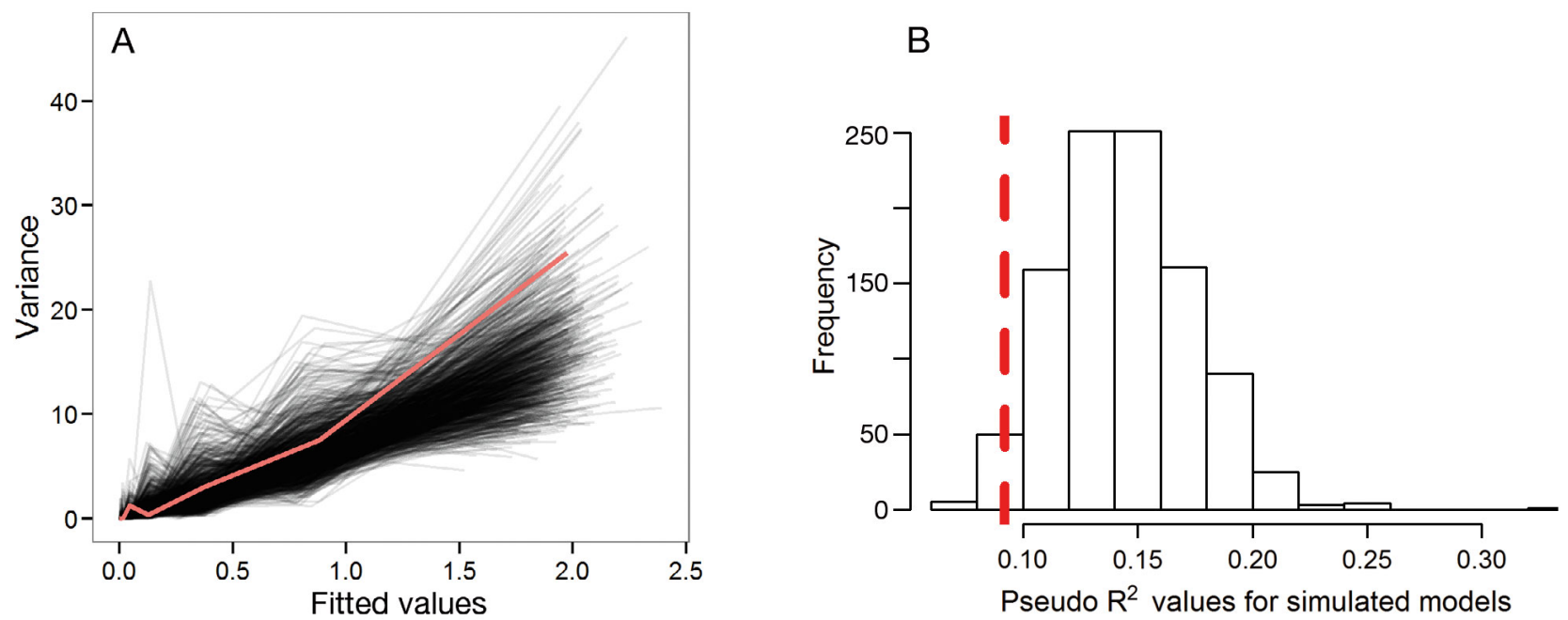

Fig. 3. Coastal area model assessment. (A) Mean variances of simulated models (black lines) generated using data set from this study assuming over-dispersed Poisson distribution. The red line shows the value obtained for the estuary model selected using SALSA. (B) Histogram of frequency of pseudo- $\mathrm{R}^{2}$ values for simulated models compared to the value obtained for the selected model (red dashed line)
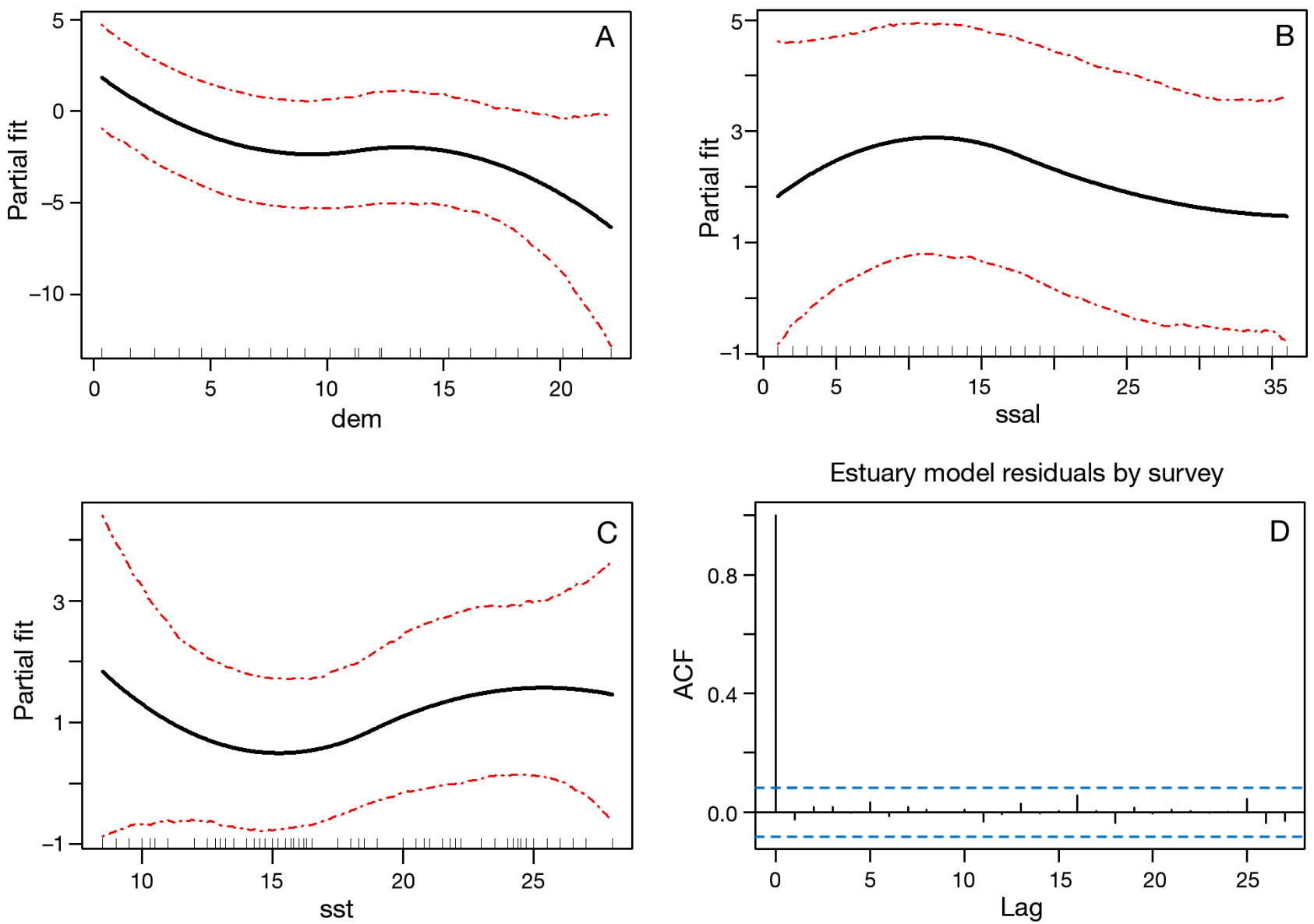

Fig. 4. Density of bottlenose dolphins Tursiops truncatus in the estuary area modeled as a smooth function of (A) distance from the estuary mouth (dem), (B) superficial salinity (ssal) and (C) sea surface temperature (sst). Dot-dashed lines represent $95 \%$ confidence intervals. A rug plot indicating sampled values is shown along the $x$-axis. (D) Autocorrelation function (ACF) plot used to assess model residual independence. Dashed lines indicate statistically significant boundaries 


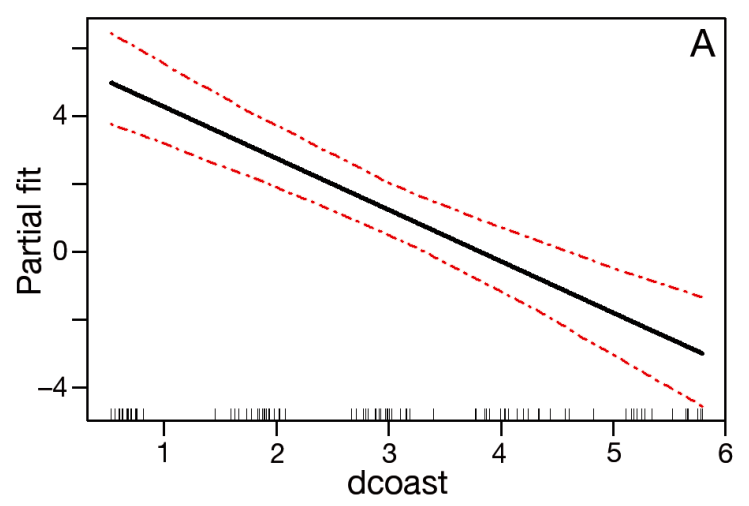

Coast model residuals by survey

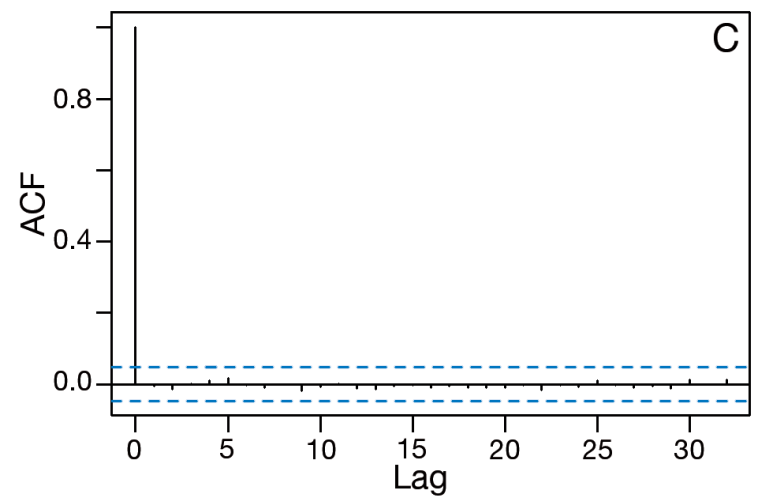

scale cetacean distribution with GAMs are a high number of zeros, spatial and temporal autocorrelations, collinearity of variables, outliers in the data and differences in survey effort. In our study, sampling effort was high ( $n=69$ surveys over 3 yr) and evenly distributed over areas and time periods, and collinearity was investigated and eliminated from the models. In addition, the use of distributions of the quasiPoisson family was opted to minimize over dispersion caused by zero-inflation and outliers in the data.

The distribution pattern of bottlenose dolphins inhabiting the PLE and adjacent marine coast varied seasonally and was influenced mainly by spatial variables. Bottlenose dolphins were observed in the estuary throughout the year and higher densities occurred closer to the estuary mouth, which was similar to results from previous studies (Castello \& Pinedo 1977, Mattos et al. 2007). This region is characterized by dense populations of a few fish species (Vieira \& Musick 1994, Garcia et al. 2012), and thus supplies high quantities of food to the dolphins. Mattos et al. (2007) frequently observed dolphins foraging near the estuary mouth. This area in the lower estuary, close to its mouth, is characterized by deeper waters $(\sim 18 \mathrm{~m})$ and steep slopes compared to the upper estuary. Areas close to the estuary mouth are subject to higher variations in current speed and direction,

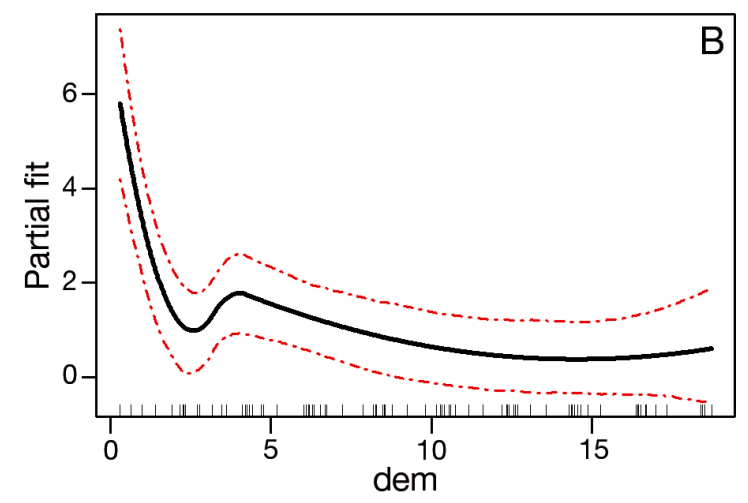

Fig. 5. Density of bottlenose dolphins Tursiops truncatus in the coastal area modeled as a smooth function of (A) distance from the coastline (dcoast), (B) distance from the estuary mouth (dem). Dashed lines represent 95\% confidence intervals. A rug plot indicating sampled values is shown along the $x$-axis. (C) Autocorrelation function (ACF) plot used to assess model residual independence. Dashed lines indicate statistically significant boundaries

which changes the water salinity, temperature and their gradients according to the interaction of water discharge and strength of north-easterlies and southwesterlies (Möller et al. 2001, Castelão \& Möller 2003). Such variability induced by seasonal forcing affects many estuarine-dependent fish species that are abundant in the estuary and adjacent coast (e.g. Garcia et al. 2012, Rodrigues \& Vieira 2013), and thus

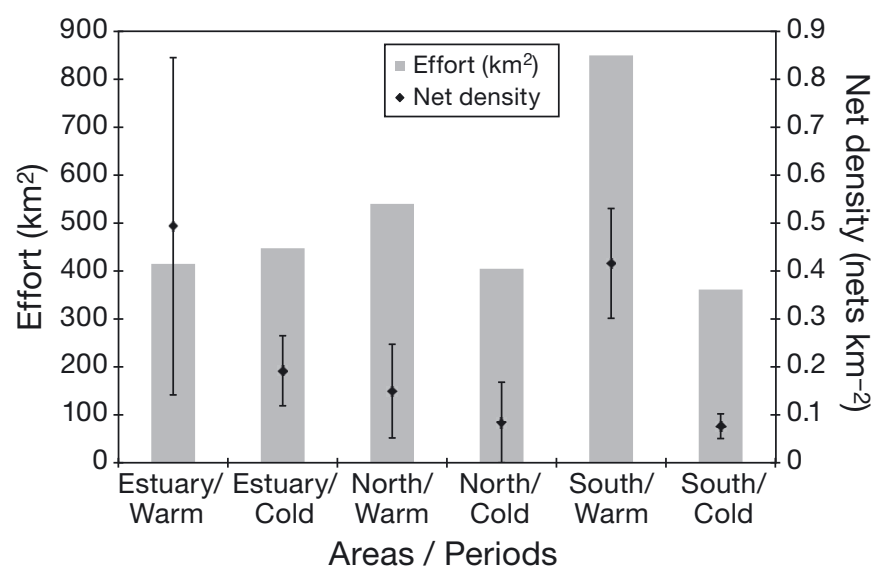

Fig. 6. Mean density of fishing nets (nets $\mathrm{km}^{-2}$ ) (black diamonds; vertical black lines show SE) and sampling effort $\left(\mathrm{km}^{2}\right)$ (grey bars) in each area (estuary, north coast, south coast) and period (warm, cold) surveyed in the Patos Lagoon estuary and adjacent coastal areas of southern Brazil 

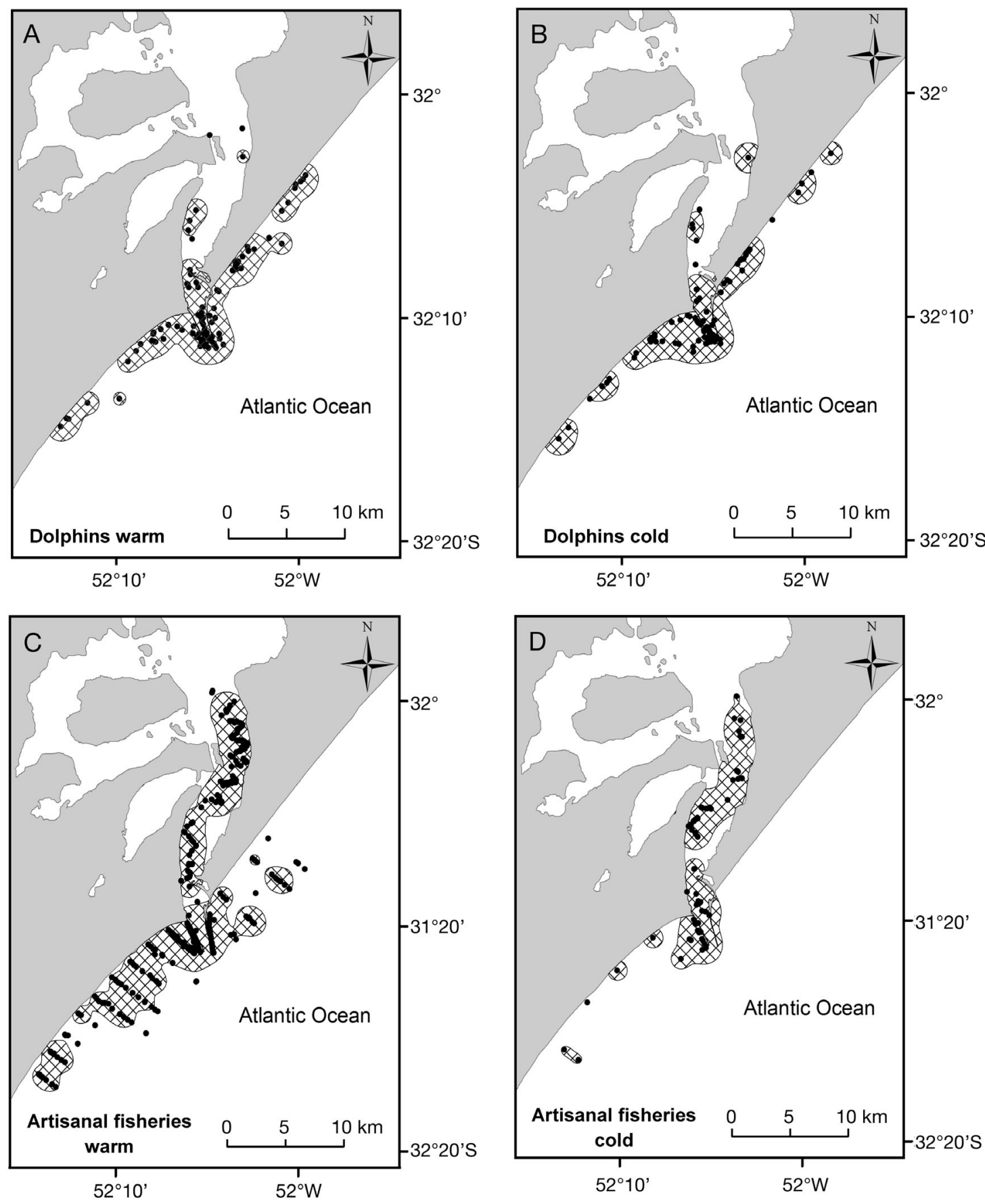

Fig. 7. Representative areas (RAs) used by bottlenose dolphins Tursiops truncatus in (A) warm and (B) cold periods, and by artisanal fisheries in (C) warm and (D) cold periods between September 2007 and July 2009 in the Patos Lagoon estuary and adjacent coastal areas of southern Brazil. Black dots are sighting locations

may change the prey distribution and availability for dolphins. In other estuaries worldwide, areas where dolphins concentrate are also related to foraging sites (Ballance 1992, Hastie et al. 2003, 2004). A preference for areas with steep slopes and strong currents has been also observed in other estuaries (e.g. Ingram \& Rogan 2002) as well as in coastal waters of the North Atlantic (e.g. Robinson et al. 2007); possibly these conditions facilitate prey capture.

The estuarine-dependent fish species whitemouth croaker, Brazilian flounder Paralichthys orbignyanus and the mullet Mugil liza are the main prey for these dolphins (Pinedo 1982, Lopez 2013). During periods of higher precipitation, as occurs during El Niño 

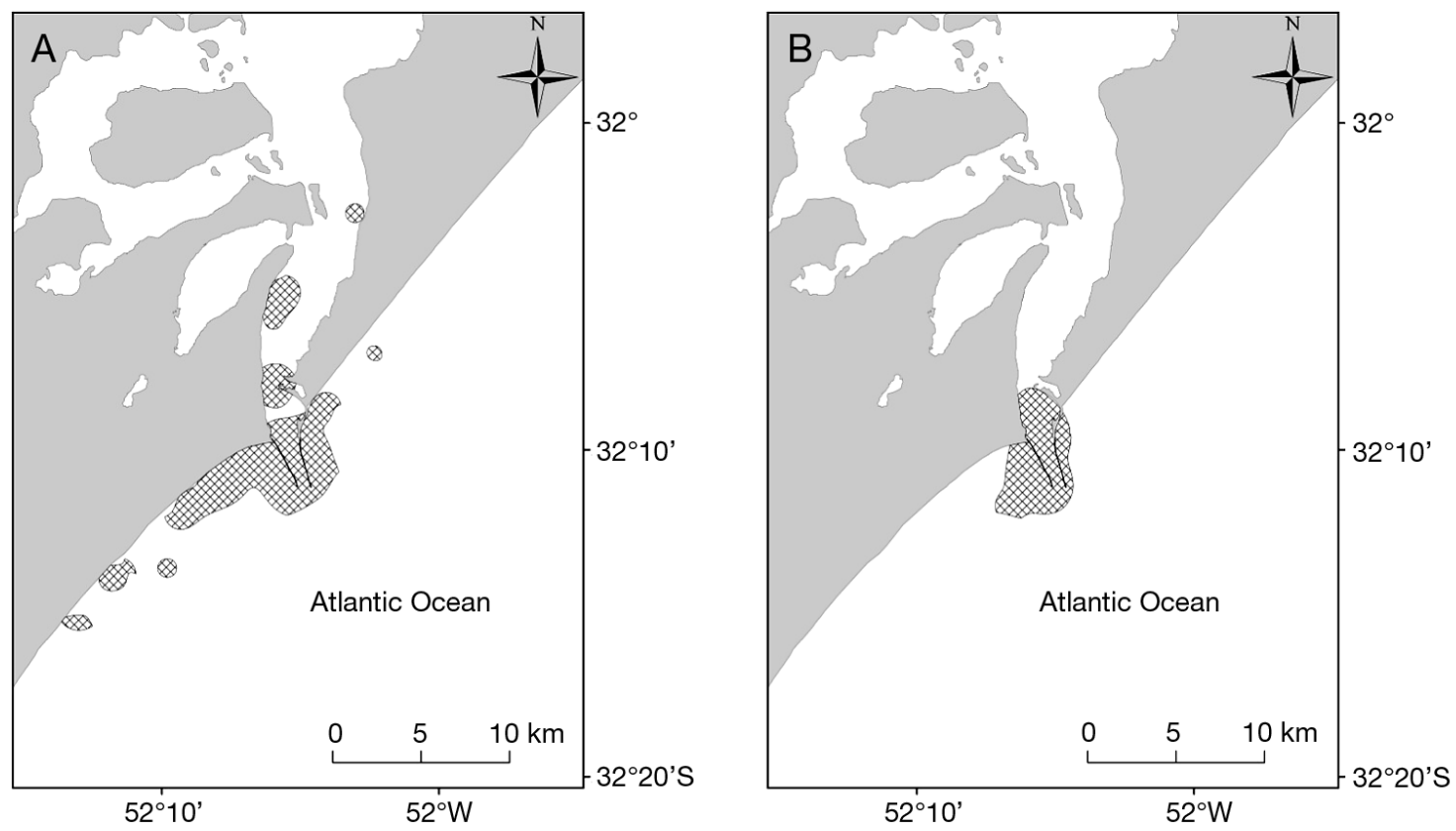

Fig. 8. Areas of overlap between bottlenose dolphins Tursiops truncatus and artisanal fishery activity in (A) warm and (B) cold periods in the Patos Lagoon estuary and adjacent coastal areas of southern Brazil

years, freshwater predominates and salinity remains low. This affects the distribution and diversity of all estuarine-dependent species, which in turn leads to higher densities in the adjacent coastal area (Garcia et al. 2003). In addition, Vieira et al. (2008) suggest that during periods with less saline water intrusion into the estuary, schools of mullet that would aggregate for the reproductive migration remain dispersed. These variations in the occurrence of potential prey for bottlenose dolphins might directly affect their distribution and may explain the relationship between dolphin relative density and water temperature and salinity observed in this study.

The spatial distribution pattern on the marine coast area showed that relative density of dolphins decreased as the distance from the estuary mouth and shore increased. Although there have been long movements reported for individuals of this community in waters ca. $250 \mathrm{~km}$ south of our study area (Laporta 2009) and for other coastal bottlenose dolphins around the world (Wells et al. 1999, Robinson et al. 2012), these dolphins are often closely associated with estuaries and productive bays (e.g. Ballance 1990, Simões-Lopes \& Fabián 1999, Ingram \& Rogan 2002). Fish species that are commonly captured by artisanal fisheries in these shallow, nearshore waters and adjacent to the estuary mouth (Klippel et al. 2005, Leal \& Bemvenuti 2006, Rodrigues \& Vieira 2013), such as banded croaker Para- lonchurus brasiliensis, cutless fish Trichiurus lepturus and southern king croaker Menticirrhus sp., are also prey of this bottlenose dolphin community (Lopez 2013).

The lower relative density of dolphins in the south area during the warm period could be due to dolphins avoiding the increased human-related disturbance during the late spring and especially austral summer months. Specifically, Cassino beach, located $6 \mathrm{~km}$ south of the PLE, attracts about 200000 tourists during summer, which contrasts with the 20000 local residents. In this period, fishing activities as well as swimmers, recreational boats, jet skis and a high volume of traffic moving along the sand beach (Fig. 9A,B) are likely to increase underwater noise considerably, which might disturb either the dolphins or their prey. These jet skis and boats concentrate within $1 \mathrm{~km}$ of shore and around the estuary entrance. The effort of artisanal gillnet fisheries targeting white croaker is higher in spring and summer (Fig. 9A) (Reis et al. 1994, Kalikoski \& Vasconcellos 2012) and occasional illegal gillnet fishing for the Brazilian guitarfish Rhinobatos horkelli (S. Estima pers. comm.) also take place during summer. It has been noted that some bottlenose dolphin populations can change their preferred habitats to avoid areas of major shipping traffic (Lusseau 2005) or temporally leave areas affected by intense noises caused by anthropogenic activities (Brandt et al. 2011, Pirotta et 
al. 2013). Allen \& Read (2000) suggested that movement of vessels indirectly affects dolphins' habitat selection by interfering with prey availability. Longterm studies are needed to confirm this pattern of distribution and the potential effect of noise on dolphin habitat selection.

\section{Distribution overlap between dolphins and fisheries}

During the present study, the spatial distributions of dolphins and fishing activities were obtained simultaneously and, therefore, the areas of higher bycatch risk were identified. The results showed clearly that the artisanal fisheries expanded their effort to the coastal areas in the warm period, resulting in a considerable increase in the overlap area with bottlenose dolphins. Fruet et al. (2012) investigated trends in mortality of bottlenose dolphins along the southern portion of Rio Grande do Sul State coast from 1969 to 2006. They found an increased number of stranded carcasses with clear signs of bycatch in areas adjacent to the PLE after 2002, and a marked seasonal pattern of mortality (during spring and summer). This information together with the findings of this study reinforces that this dolphin mortality pattern is related to the artisanal fishing activities during the warm period in the areas adjacent to the estuary.

The fact that prey species consumed by dolphins and targeted by the artisanal coastal fisheries are the same probably promotes the overlap in their distributions. Only 11 bottlenose dolphins were found washed ashore during the period of this study (September 2006 to July 2009; ECOMEGA, unpubl. data), a low number when compared to the 49 carcasses found washed ashore between 2002 and 2006 (Fruet et al. 2012). Events such as El Niño and La Niña influence rainfall and salinity in this area, causing changes in the distribution, abundance and recruitment of fish stocks and shrimp in this region (D'Incao et al. 2002, Garcia et al. 2003, Möller et al. 2009). During years of poor shrimp harvests, fishermen increases gillnet fishing effort targeting white croaker, squirrel hake Urophycis brasiliencis and blue crab Callinectes sapidus to offset economic losses (Fruet et al. 2012). During the austral summer 2006-2007 El Niño was weak, with low precipitation rates allowing for the intrusion of salt water and shrimp larvae, which resulted in a good shrimp harvest (Pereira 2010). According to technical reports of artisanal fishery landings provided by the local governmental environ-
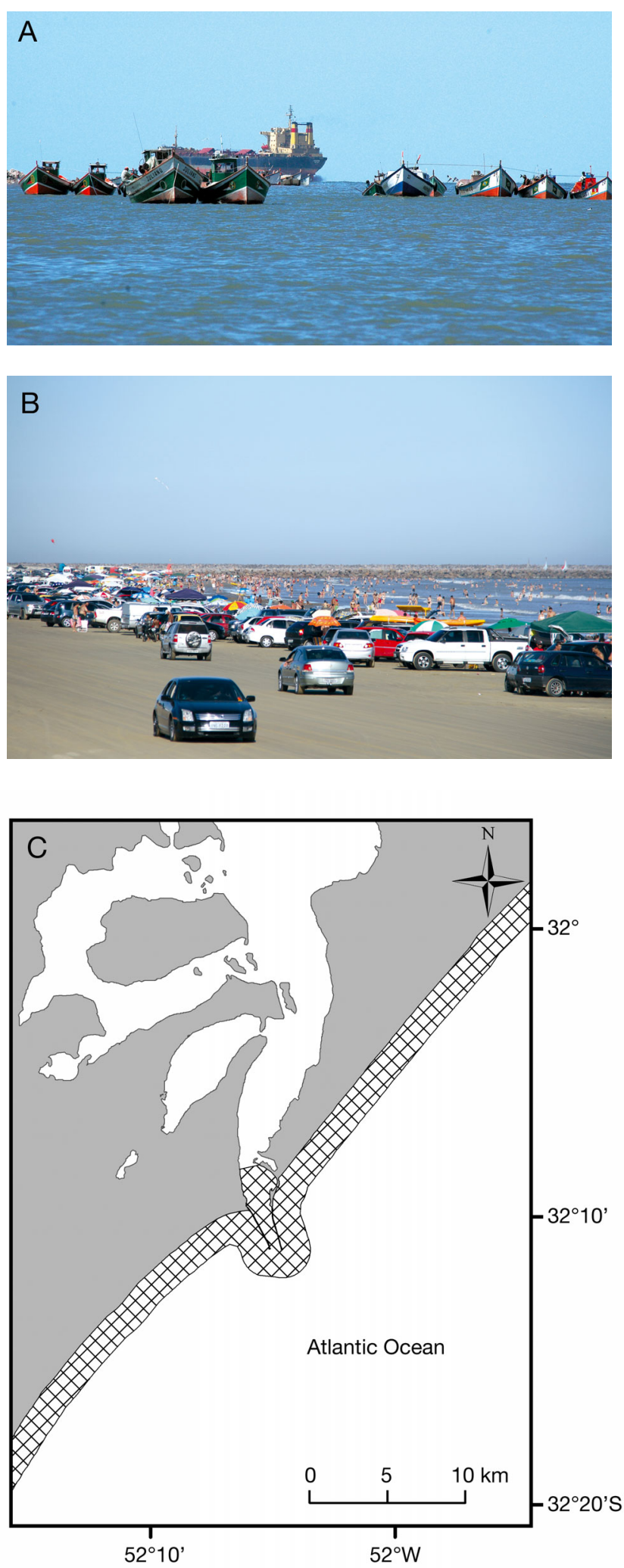

Fig. 9. (A) Artisanal fishing boats in the Patos Lagoon estuary mouth. (B) Tourists during summer on Cassino Beach. (C) Fishing exclusion area suggested based on the results of this study 
mental agency (CEPERG/IBAMA, www.icmbio.gov. br/ceperg/publicacoes.html), the 2006-2007 shrimp harvest was followed by a marked decline in subsequent years, reaching minimal values in 2009-2010. Therefore, artisanal gillnet fishing effort was probably much higher during the warm period of 20082009 and the following years of continued low shrimp harvest. As mentioned earlier, the period of increased fishing effort in the coastal area coincides with the harvest of white croaker, which is an important economic resource for the artisanal fishery in this region (Reis \& D'Incao 2000, Kalikoski \& Vasconcellos 2012).

\section{Establishment of a dolphin protected area in 2012}

In order to reduce mortality among this small dolphin community, the results of this study were used as a framework to design a fishing exclusion area, which was discussed with local stakeholders. In August 2012, the Ministry of Fisheries and Aquiculture and the Ministry of Environment jointly created a resolution to regulate the gillnet fisheries in the southern and southeastern states of Brazil (Brasil 2012). This resolution prohibits gillnet fishing within the first $5 \mathrm{~km}$ inside the estuary, around the jetties and the adjacent marine coast. Along the marine coast this no-gillnet zone extends 1 nautical mile $(1.8 \mathrm{~km})$ from shore and $20 \mathrm{~km}$ south and north of the Patos Lagoon entrance (Fig. 9C). It is unlikely that this regulation will cause drastic changes in the local fishing dynamic or in fishermen's incomes, as they will need to move only a very short distance from their previous main fishing sites. When artisanal fishermen leave the estuary they have to bypass the jetties that extend up to $4 \mathrm{~km}$ into the ocean. Thus, when they reach the marine coast they are already outside the fishing exclusion area, except in areas around the end of the jetties. In fact, they would have to navigate back towards the coast to set the nets within the protected area.

Despite the relatively short period of this study, the distribution of bottlenose dolphins was consistent with results of previous studies (e.g. Mattos et al. 2007). Since the boundaries of the protected area were designed in accordance with the results of the present study and the distribution of the dolphins has not changed over the years, this no-take zone for gillnetting can be expected to be effective in avoiding bycatch. Unfortunately, our marine coast surveys were spatially limited to $20 \mathrm{~km}$ north and south from the jetties (for logistical reasons we could not survey more distant areas along the coast) and, therefore, may not be sufficient to reduce bycatch in areas along the coast outside the protected area. Although the results showed higher dolphin densities near the estuary mouth, where feeding, breeding and calving take place, movements further away along the coast are known to occur (Laporta 2009). In addition, other dolphin communities roam along the adjacent marine coast (Genoves 2013) and are also susceptible to bycatch. All these bottlenose dolphin communities present very low levels of genetic diversity (Fruet et al. 2014). A recent population viability analysis has demonstrated that the removal of 1 mature female per year due to bycatch would result in a high probability of decline of the small PLE dolphin community (Fruet 2014). Reducing non-natural mortality by protecting the core and adjacent areas used by this small dolphin community can help reduce risks of decline and, most importantly, promote population growth. The latter would enhance connectivity and increase gene flow with the adjacent communities, which is desirable for increasing the long-term viability of bottlenose dolphins in southern Brazil. Nevertheless, it is recommended that systematic surveys are maintained in order to detect potential changes in bottlenose dolphin distribution patterns and to assess whether or not this gillnet fishery regulation is being followed, is effective in reducing bycatch, and allows for an economically viable fishery.

Acknowledgements. We thank the Organization for the Conservation of South American Aquatic Mammals (YAQU PACHA), Cetacean Society International, Rufford Small Grants and Idea Wild for the financial support. This study was made possible thanks to logistical support provided by the staff, students of the Museu Oceanográfico 'Prof. Eliézer C. Rios', Laboratório de Ecologia e Conservação da Megafauna Marinha - Universidade Federal do Rio Grande (ECOMEGA-FURG) and the National Council for Scientific and Technological Development (CNPq) under the framework of the Brazilian Long-Term Ecological Research (BRLTER). We are especially grateful to R. Genoves for field assistances and S. Botta for comments on the early drafts of the manuscript. We thank Pablo Bech for the photograph of tourists in Cassino beach. The CNPQ provided a scholarships to J.C.D.T., a research fellowship to E.R.S. (PQ 307846/ 2014) and Coordenação de Aperfeiçoamento de Pessoal de Nível Superior (CAPES) scholarship to P.F.F. This is a contribution of the Research Group 'Ecologia e Conservação da Megafauna Marinha (EcoMega-CNPq).

\section{LITERATURE CITED}

Abreu PC, Castello JP (1998) Interações entre os ambientes estuarino e marinho. In: Seeliger U, Odebrecht C, Castello JP (eds) Os ecosistemas costeiro e marinho do extremo sul do Brasil. Ecoscientia, Rio Grande, p 199-204 
Acevedo-Gutierrez A, Parker N (2000) Surface behavior of bottlenose dolphins is related to spatial arrangement of prey. Mar Mamm Sci 16:287-298

Allen MC, Read AJ (2000) Habitat selection of foraging bottlenose dolphins in relation to boat density near Clearwater, Florida. Mar Mamm Sci 16:815-824

> Atwood TC, Weeks HP (2003) Spatial home-range overlap and temporal interaction in eastern coyotes: the influence of pair types and fragmentation. Can J Zool 81: 1589-1597

Ayres M, Ayres M Jr, Murcia C, Ayres DL, Santos AAS (2007) BioEstat: aplicaciones estadisticas para las ciencias biológicas y medicas. ONG Mamirauá, Belém

Ballance LT (1990) Residence patterns, group organization, and surfacing associations of bottlenose dolphins in Kino Bay, Gulf of California, Mexico. In: Leatherwood S, Reeves R (eds) The bottlenose dolphin. Academic Press, San Diego, CA, p 267-283

Ballance LT (1992) Habitat use patterns and ranges of the bottlenose dolphins in the Gulf of California, Mexico. Mar Mamm Sci 8:262-274

Brandt MJ, Diederichs A, Betke K, Nehls G (2011) Responses of harbour porpoises to pile driving at the Horns Rev II offshore wind farm in the Danish North Sea. Mar Ecol Prog Ser 421:205-216

Brasil (2012) Instrução Normativa Interministerial MPA/ MMA número 12 de 22 de agosto de 2012. Dispõe sobre critérios e padrões para o ordenamento da pesca praticada com o emprego de redes de emalhe nas águas jurisdicionais brasileiras das regiões Sudeste e Sul. Diário Oficial da União de 24.08.2012, n165, Seção 1, p 39

Brown SL, Reid D, Roga E (2013) A risk-based approach to rapidly screen vulnerability of cetaceans to impacts from fisheries bycatch. Biol Conserv 168:78-87

Buckland ST, Anderson DR, Burnham KP, Laake JL, Borchers DL, Thomas L (2001) Introduction to distance sampling. Oxford University Press, Oxford

Castelão RM, Möller OO (2003) Sobre a circulação tridimencional forçada por ventos na Lagoa dos Patos. Atlantica 25:91-106

Castello HP, Pinedo MC (1977) Botos na Lagoa dos Patos. Natureza em Revista 2:46-49

D'Incao F, Valentini H, Rodrigues LF (2002) Avaliação da pesca de camarões nas regiões Sudeste e Sul do Brasil (1965-1999). Atlantica 24:49-62

> Diáz López B (2006) Interactions between Mediterranean bottlenose dolphins (Tursiops truncatus) and gillnets off Sardinia, Italy. ICES J Mar Sci 63:946-951

> Dumont LFC, D'Incao F (2011) Bycatch analysis of Argentinean prawn Artemesia longinaris (Decapoda: Penaeidae) in surrounding area Patos Lagoon, southern Brazil: effects of different rainfall. J Mar Biol Assoc UK 91: 1059-1072

ESRI (Environmental Systems Research Institute) (2001) ArcGis 9: using ArcGis Spatial Analyst. ESRI, Redlands, CA, p 133-138

Fernández R, Begoña-Santos M, Pierce GJ, Llavona A and others (2011) Fine-scale genetic structure of bottlenose dolphins, Tursiops truncatus, in Atlantic coastal waters of the Iberian Peninsula. Hydrobiologia 670:111-125

Fox J, Weisberg S (2011) An R companion to applied regression, 2nd edn. Sage, Thousand Oaks, CA

Fruet PF (2014) Estrutura genética, dinâmica e viabilidade populacional do boto,tursiops truncatus, do estuário da lagoa dos patos, sul do Brasil. PhD thesis, Universidade Federal do Rio Grande

- Fruet PF, Secchi ER, Di Tullio JC, Kinas PG (2011) Abundance estimation of bottlenose dolphins, Tursiops truncatus (Cetacea: Delphinidae) inhabiting Patos Lagoon estuary, southern Brazil: implications for conservation. Zoologia 28:23-30

Fruet PF, Kinas PG, Da Silva KG, Di Tullio JC and others (2012) Temporal trends in mortality and effects of fishing bycatch on bottlenose dolphins, Tursiops truncatus, in southern Brazil. J Mar Biol Assoc UK 91:1-12

Fruet PF, Secchi ER, Daura-Jorge F, Vermeulen E and others (2014) Remarkably low genetic diversity and hierarchical population structure in common bottlenose dolphins (Tursiops truncatus) from coastal waters of the Southwestern Atlantic Ocean. Conserv Genet 15:879-895

Fruet PF, Daura-Jorge F, Möller LM, Genoves RC, Secchi ER (2015) Abundance and demography of bottlenose dolphins inhabiting a subtropical estuary in the Southwestern Atlantic Ocean. J Mammal 96:332-343

Garcia AM, Vieira JP, Winemiller KO (2003) Effects of 1997-1998 El Niño on the dynamics of the shallow-water fish assemblages of Patos Lagoon Estuary (Brazil). Estuar Coast Shelf Sci 57:489-500

Garcia AM, Vieira JP, Winemiller KO, Moraes LE, Paes ET (2012) Factoring scales of spatial and temporal variation in fish abundance in a subtropical estuary. Mar Ecol Prog Ser 461:121-135

Genoves RC (2013) Estrutura social do boto, Tursiops truncatus (Cetacea:Delphinidae) no estuário da Lagoa dos Patos e águas costeiras adjacentes, sul do Brasil. MSc dissertation, Universidade Federal do Rio Grande

Gonzalvo J, Valls M, Cardona L, Aguilar A (2008) Factors determining the interaction between common bottlenose dolphins and bottom trawlers off the Balearic Archipelago (western Mediterranean Sea). J Exp Mar Biol Ecol 367:47-52

Haimovici M, Vasconcellos M, Kalikoski DC, Abdalah P, Castello JP, Hellebrandt D (2006) Diagnóstico da pesca no litoral do estado do Rio Grande do Sul. In: Isaac VJ, Martins AS, Haimovici M, Andriguetto Filho JM (eds) A pesca marinha e estuarina do Brasil no início do século XXI: recursos, tecnologias, aspectos socioeconômicos e institucionais. Editora Universitária, Pará

Hastie TJ, Tibshirani RJ (1990) Generalized additive models. Chapman \& Hall, London, p 82-170

Hastie GD, Barton TR, Grellier K, Hammond PS, Swift RJ, Thompson PM, Wilson B (2003) Distribution of small cetaceans within a candidate special area of conservation; implications for management. J Cetacean Res Manag 5:261-266

Hastie GD, Wilson B, Wilson LJ, Parsons KM, Thompson PM (2004) Functional mechanisms underlying cetacean distribution patterns: hotspots for bottlenose dolphins are linked to foraging. Mar Biol 144:397-403

Heithaus MR, Dill M (2002) Food availability and tiger shark predation risk influence bottlenose dolphin habitat use. Ecology 83:480-491

Heithaus MR, Dill LM (2006) Does tigershark predation risk influence foraging habitat use by bottlenose dolphins at multiple spatial scales? Oikos 114:257-264

> Ingram SN, Rogan E (2002) Identifying critical areas and habitat preferences of bottlenose dolphins Tursiops truncatus. Mar Ecol Prog Ser 244:247-255

Kalikoski DC, Vasconcellos M (2012) Case study of the technical, socio-economic and environmental conditions of 
small-scale fisheries in the estuary of Patos Lagoon, Brazil: a methodology for assessment. FAO Fisheries and Aquaculture. Circular 1075, Food and Agriculture Organization, Rome

Kalikoski DC, Vasconcellos M, Lavkulich ML (2002) Fitting institutions and ecosystems: the case of artisanal fisheries management in the Patos lagoon. Mar Policy 26: 179-196

Kjervfe B (1986) Comparative oceanography of coastal lagoons. In: Wolfe DA (eds) Estuarine variability. Academic Press, New York, NY, p 63-81

Klippel S, Peres MB, Vooreen CM, Lamónaca AF (2005) A pesca artesanal na costa da plataforma sul. In: Vooreen CM, Klippel S (eds) Ações para a conservação de tubarões e raias no sul do Brasil. Instituto Igaré, Porto Alegre, p 179-198

Laporta P (2009) Abundância, distribuição e uso do habitat do boto (Tursiops truncatus) em Cabo Polonio e La Coronilla (Rocha, Uruguai). MSc dissertation, Universidade Federal do Rio Grande

Leal LCN, Bemvenuti MA (2006) Levantamento e caracterização dos peixes mais frequentes no mercado público do Rio Grande. Cadernos de Ecologia 1:45-61

Lopez LA (2013) Ecologia alimentar de dois predadores de topo simpátricos que habitam um estuário subtropical e costa adjacente, no oeste do Atlântico Sul. MSc dissertation, Universidade Federal do Rio Grande

> Lusseau D (2005) Residency pattern of bottlenose dolphins Tursiops spp. in Milford Sound, New Zealand, is related to boat traffic. Mar Ecol Prog Ser 295:265-272

MacLeod CD, Santos MB, Burns F, Brownlow A, Pierce GJ (2014) Can habitat modelling for the octopus Eledone cirrhosa help identify key areas for Risso's dolphin in Scottish waters? Hydrobiologia 725:125-136

Mattos PH, Dalla Rosa L, Fruet PF (2007) Activity budgets and distribution of bottlenose dolphins (Tursiops truncatus) in the Patos Lagoon estuary, southern Brazil. Lat Am J Aquat Mamm 6:161-169

McCullagh P, Nelder JA (1989) Generalized linear models, 2nd edn. Chapman Hall, New York, NY

> Möller OO, Castaing P, Salomon JC, Lazure P (2001) The influence of local and non-local forcing effects on the subtidal circulation of Patos Lagoon. Estuaries 24: 297-311

Möller OO, Castello JP, Vaz AC (2009) The effect of river discharge and winds on the interannual variability of the pink shrimp Farfantepenaeus paulensis production in Patos Lagoon. Estuar Coast 32:787-796

Noke WD, Odell D (2002) Interactions between the Indian River Lagoon blue crab fishery and the bottlenose dolphin, Tursiops truncatus. Mar Mamm Sci 18:819-832

Parra GJ (2006) Resource partitioning in sympatric delphinids: space use and habitat preferences of Australian snubfin and Indo-Pacific humpback dolphins. J Anim Ecol 75:862-874

Parsons KM, Noble LR, Reid RJ, Thompson PM (2002) Mitochondrial genetic diversity and population structuring of UK bottlenose dolphins (Tursiops truncatus): Is the NE Scotland population demographically and geographically isolated? Biol Conserv 108:175-182

Pereira N (2010) Influência dos fatores meteorológicos na salinidade e na abundância da safra de camarão-rosa, Farfantepenaeus paulensis, Perez Farfante, 1967, no estuário da Lagoa dos Patos, Sul do Brasil. MSc dissertation, Universidade Federal do Rio Grande
Pinedo C (1982) Análise dos conteúdos estomacias de Pontoporia blainvillei (Gervais and D'Orbigny, 1844) e Tursiops gephyreus (Lahille, 1908) (Cetacea, Platanistidae e Delphinidae) na zona estuarial e costeira de Rio Grande, RS, Brasil. MSc dissertation, Universidade Federal do Rio Grande

> Pirotta E, Laesser BE, Hardaker A, Riddoch N, Marcoux M, Lusseau D (2013) Dredging displaces bottlenose dolphins from an urbanised foraging patch. Mar Pollut Bull 74:396-402

R Development Core Team (2014) R: a language and environment for statistical computing. R Foundation for Statistical Computing, Vienna

Redfern JV, Ferguson MC, Becker EA, Hyrenbach KD and others (2006) Techniques for cetacean-habitat modeling. Mar Ecol Prog Ser 310:271-295

Reeves RR, Smith BD, Crespo E, Notarbartolo di Sciara G (2003) Dolphins, whales, and porpoises: 2002-2010 conservation action plan for the world's cetaceans. IUCN/ SSB Cetacean Specialist Group, Cambridge

Reeves RR, McClellan K, Werner TB (2013) Marine mammal bycatch in gillnet and other entangling net fisheries, 1990 to 2011. Endang Species Res 20:71-97

Reis EG, D'Incao F (2000) The present status of artisanal fisheries of extreme southern Brazil: an effort towards community-based management. Ocean Coast Manag 43: 585-595

Reis EG, Vieira PC, Duarte VS (1994) Pesca artesanal de teleósteos no estuário da Lagoa dos Patos e costa do Rio Grande do Sul. Atlantica 16:69-86

Robinson KP, Baumgartner N, Eisfeld SM, Clark N and others (2007) The summer distribution and occurrence of cetaceans in the coastal waters of Moray Firth, in northeast Scotland (UK). Lutra 50:13-26

Robinson KP, O' Brien JM, Berrow SD, Cheney B and others (2012) Discrete or not so discrete: long distance movements by coastal bottlenose dolphins in UK and Irish waters. J Cetacean Res Manag 12:365-371

Rodrigues FL, Vieira JP (2013) Surf zone fish abundance and diversity at two sandy beaches separated by long rocky jetties. J Mar Biol Assoc UK 93:867-875

Scott-Hayward LAS, Oedekoven CS, Mackenzie ML, Walker CG, Rexstad E (2013) User guide for the MRSea package: statistical modelling of bird and cetacean distributions in oshore renewables development areas. Universiy of St. Andrews contract for marine Scotland SB9 (CR/2012/05)

Simões-Lopes PC, Fabián ME (1999) Residence patterns and site fidelity in bottlenose dolphins, Tursiops truncatus (Montagu) (Cetacea, Delphinidae) off Southern Brazil. Rev Bras Zool 16(4):1017-1024

Stolen M, Durden WN, Mazza T, Barros N, Leger J St (2013) Effects of fishing gear on bottlenose dolphins (Tursiops truncatus) in the Indian River Lagoon system, Florida. Mar Mamm Sci 29(2):356-364

Tagliani PRA, Landazuri H, Reis EG, Tagliani CR, Asmus ML, Sánchez-Arcilla A (2003) Integrated coastal zone management in the Patos Lagoon estuary: perspectives in developing country. Ocean Coast Manag 46:807-822

> Tezanos-Pinto G, Baker CS, Russell K, Martien KK and others (2009) A worldwide perspective on the population structure and genetic diversity of bottlenose dolphins (Tursiops truncatus) in New Zealand. J Hered 100:11-24

Torres LG, Read AJ, Halpin P (2008) Fine-scale habitat modeling of a top marine predator: Do prey data improve 
predictive capacity? Ecol Appl 18:1702-1717

Venables N, Dichmont M (2004) GLMs, GAMs and GLMMs: an overview of theory for applications in fisheries research. Fish Res 70:319-337

Vieira JP, Garcia AM, Grimm AM (2008) Evidences of El Niño effects on the mullet fishery of the Patos Lagoon estuary. Braz Arch Biol Tech 51:433-440

Vieira JP, Musick JA (1994) Fish faunal composition in warmtemperate and tropical estuaries of western Atlantic. Atlantica 16:31-53

Walker C, Mackenzie M, Donovan C, O'Sullivan M (2011) SALSA - a spatially adaptive local smoothing algorithm. J Stat Comput Sim 81:179-191

Waples DM, Thorne LH, Hodge LEW, Burke EK, Urian KW, Read AJ (2013) A field test of acoustic deterrent devices used to reduce interactions between bottlenose dolphins and a coastal gillnet fishery. Biol Conserv 157:163-171

Watson DF (1992) Contouring: a guide to the analysis and display of spatial data. Elsevier, Oxford

Wells RS, Scott MD (1999) Bottlenose dolphin Tursiops truncatus (Montagu, 1821). In: Ridgway SH, Harrison SR

Editorial responsibility: Eric Gilman,

Honululu, Hawaii, USA (eds) Handbook of marine mammals 6: the second book of dolphins and porpoises. Academic Press, London, p 137-182

Wells RS, Scott MD, Irvine AB (1987) The social structure of freeranging bottlenose dolphins. In: Genoways $H$ (ed) Current mammalogy. Plenum Press, New York, NY, p 247-305

Wells RS, Rhinehart HL, Cunningham P, Whaley J, Baran M, Koberna C, Costa PD (1999) Long distance offshore movements of bottlenose dolphins. Mar Mamm Sci 15: 1098-1114

Wickham H (2009) ggplot2: elegant graphics for data analysis. Springer, New York, NY

Zuur AF, Ieno EN, Smith GM (2007) Analysing ecological data. Springer, New York, NY

Zuur AF, Ieno EN, Walker NJ, Saveliev AA, Smith GM (2009) Mixed effects models and extensions in ecology with R. Springer, New York, NY

Zuur AF, Ieno E, Elphick C (2010) A protocol for data exploration to avoid common statistical problems. Methods Ecol Evol 1:3-14

Submitted: December 11, 2013; Accepted: August 26, 2015 Proofs received from author(s): October 19, 2015 